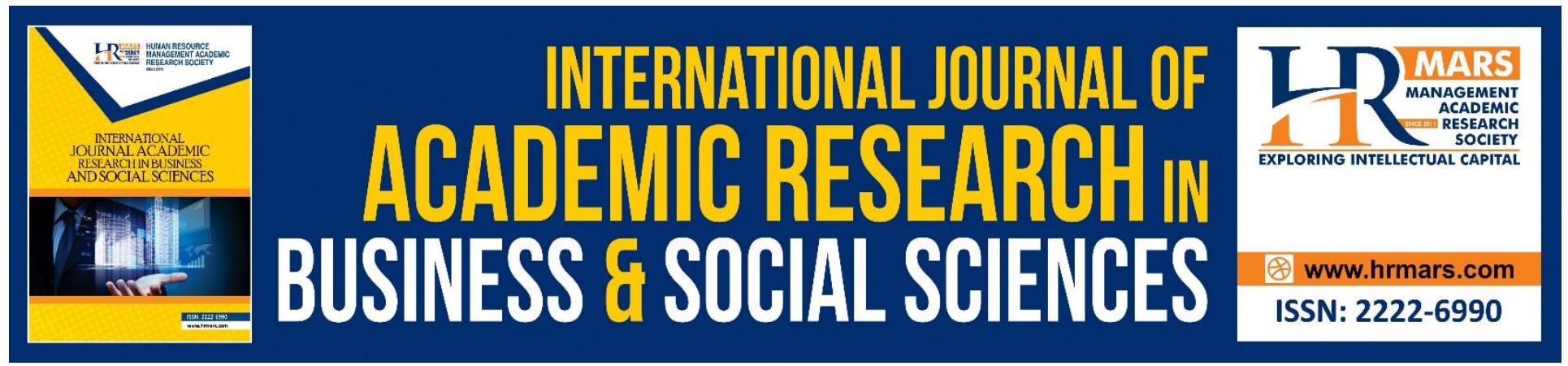

\title{
Relationship between Age Diversity and Employee Performance of Public Universities in Western Kenya
}

Mande Wycliffe Odhiambo, Hazel G. Gachoka, Charles M. Rambo

To Link this Article: http://dx.doi.org/10.6007/IJARBSS/v8-i11/4897

DOI: $10.6007 /$ IJARBSS/v8-i11/4897

Received: 20 Sept 2018, Revised: 08 Oct 2018, Accepted: 30 Oct 2018

Published Online: 25 Nov 2018

In-Text Citation: (Odhiambo, Gachoka, \& Rambo, 2018)

To Cite this Article: Odhiambo, M. W., Gachoka, H. G., \& Rambo, C. M. (2018). Relationship between Age Diversity and Employee Performance of Public Universities in Western Kenya. International Journal of Academic Research in Business and Social Sciences, 8(11), 223-248.

\section{Copyright: (C) 2018 The Author(s)}

Published by Human Resource Management Academic Research Society (www.hrmars.com)

This article is published under the Creative Commons Attribution (CC BY 4.0) license. Anyone may reproduce, distribute, translate and create derivative works of this article (for both commercial and non-commercial purposes), subject to full attribution to the original publication and authors. The full terms of this license may be seen

at: http://creativecommons.org/licences/by/4.0/legalcode

Vol. 8, No. 11, 2018, Pg. 223 - 248

http://hrmars.com/index.php/pages/detail/IJARBSS

JOURNAL HOMEPAGE

Full Terms \& Conditions of access and use can be found at http://hrmars.com/index.php/pages/detail/publication-ethics 


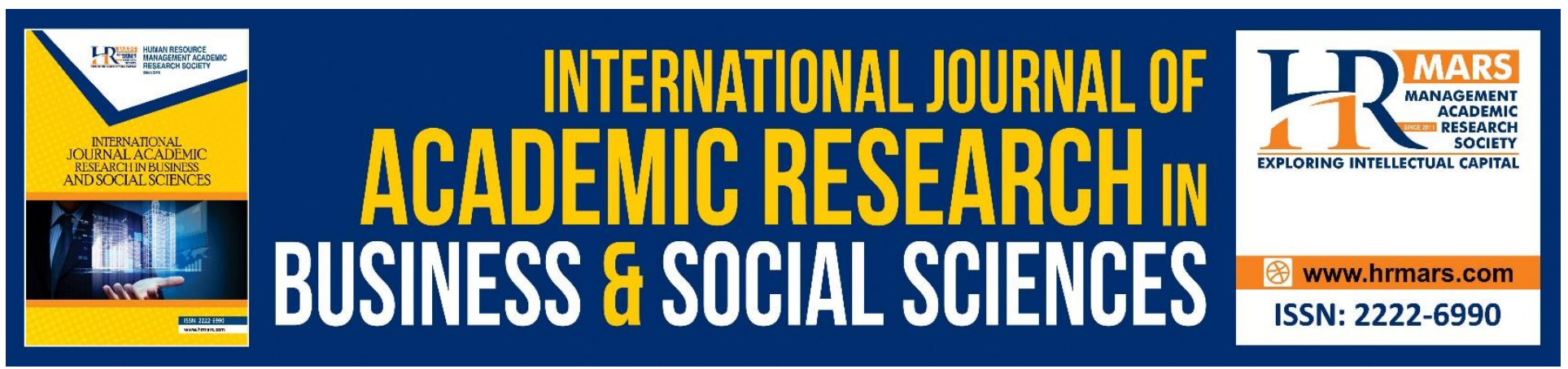

\title{
Relationship between Age Diversity and Employee Performance of Public Universities in Western Kenya
}

\author{
Mande Wycliffe Odhiambo \\ Department of Entrepreneurship and Technology, Leadership and Management, School of \\ Entrepreneurship, Leadership and Procurement, Jomo Kenyatta University of Agriculture and \\ Technology, Nairobi, Kenya \\ Email: cliffmande@yahoo.com

\begin{abstract}
Professor Hazel G. Gachoka
Department of Entrepreneurship and Technology, Leadership and Management, School of Entrepreneurship, Leadership and Procurement, Jomo Kenyatta University of Agriculture and Technology, Nairobi, Kenya

Email: hazelgac@gmail.com
\end{abstract}

\section{Professor Charles M. Rambo}

School of Continuing and Distance Education, University of Nairobi, Kenya.

Email: rambocharles@yahoo.com

\begin{abstract}
The objective of this study was to determine relationship between age diversity and employee performance of public universities in Western Kenya. The target population composed of four public universities and the respondents were 120 head of departments. The study adopted a mixed method design and a survey method was used to collect primary data using a questionnaire pretested for validity and reliability. Descriptive and inferential statistics were used to analyze the data. Out of the 120 questionnaires sent out, 93 questionnaires were received giving a response rate of $78 \%$. Regression and correlation analysis established a statistically significant positive relationship between age diversity and employee performance. The conclusions drawn from the study findings is that age diversity influence employee performance positively and majority of the employees are positive about age diversity practices in public universities. The study then recommended that the management should continue to uphold its age diversity policies and practices in order to increase the benefits of workforce diversity and come up with motivation programs that recognize younger employees in team success. Further research should be carried out on other variables of workforce diversity, test moderating variable on this relationship and a look into other institutions in public and private sectors.
\end{abstract}


INTERNATIONAL JOURNAL OF ACADEMIC RESEARCH IN BUSINESS AND SOCIAL SCIENCES

Vol. 8, No. 11, Nov, 2018, E-ISSN: 2222-6990 @ 2018 HRMARS

Keywords: Workforce Diversity, Age Diversity, Employee Performance, Public Universities, Western Kenya.

\section{INTRODUCTION}

\section{Workforce Diversity}

Increased mobility and networking of people from diverse backgrounds as a result of improved economic and political systems and the recognition of human rights by most nations has put most organizations under pressure to embrace diversity at the work place (Williams \& O'Reilly, 1998). This diversity brings with it the heterogeneity that needs to be nurtured, cultivated and appreciated as a means of increasing organization's performance. Carrell (2006) defines workforce diversity as ways that people differ which can affect a task or relationship within an organization such as age, gender, race, education and ethnicity. The concept of diversity emerged mainly to further the availability of equal opportunities in the workplace with a philosophy of ensuring that organizations make the most out of the difference from a diverse workforce rather than losing talent which might assist the organization to be more efficient and effective (Jain \& Verma, 1996).

Contemporary trends in the legal framework have also necessitated the putting in place specific statutes making it unlawful to discriminate on grounds such as age, sex, marital status, race, national origin, ethnicity, disability, sexual orientation, religion or belief, union membership or nonmembership, part-time or full time workers, or ex-offenders whose convictions are spent (Torrington, Hall \& Taylor, 2005). Cox (2001) agrees with this but argues that workforce diversity is not the sole domain of the human resource function in the organization primarily aimed at compliance with legal requirements; but it is a systematic organization-wide effort based on the premise that for organizations to survive and thrive there must be an inherent value in diversity. Cox notes that, the challenge of diversity is not simply to have it but to create conditions in which its potential to be a performance barrier is minimized and its potential to enhance performance is maximized (Cox, 2001). Diversity management therefore refers not only to those groups that have been discriminated against or that are different from the dominant or privileged groups, but to the mixture of differences, similarities and tensions that can exist among the elements of a pluralistic mixture (Thomas, 2005). Workforce diversity is a subjective phenomenon, created by group members themselves who on the basis of their different social identities categorize others as similar or dissimilar (O'Reilly, Williams, \& Barsade, 1998). Loden \& Rosener (1991) define diversity as that which differentiates one group of people from another along primary and secondary dimensions. Primary dimensions of diversity, those exerting primary influences on our identities, are gender, ethnicity, race, sexual orientation, age and mental or physical abilities and characteristics. They claim that primary dimensions shape our basic self-image as well as our fundamental world views and have the most impact on groups in the workplace and society. Secondary dimensions of diversity on the other hand are less visible, exert a more variable influence on personal identity and add a more subtle richness to the primary dimensions of diversity. They include: educational background, geographic location, religion, first language, family status, work style, work experience, military experience, organizational role and level, income and communication style. The secondary dimensions impact our self-esteem and selfdefinition (Loden \& Rosener, 1991). 


\section{Age Diversity}

Age diversity is a shared phenomenon that is present in nearly all groupings, such as families, higher institutions, sport teams, and work or team groups with members of varying ages (Kunze, Boehm, \& Bruch, 2013). Workforce is unique in its generational diversity, which presents new challenges to organizations attempting to attract, retain, manage, and motivate quality employees. Each generation believes that its strengths are unique and they do not enhance those of other generations (Rowe, 2010). Where age diversity is practiced, the benefits accrue both to the organization and the employees. Having an age diverse environment produces and creates better working relationships and enhances social cohesion for all. Age stereotypes are features given to people who belong to a specific age group. They are meant to guide individuals during the process of social interactions. Most of the time, stereotypes are based on incomplete knowledge about changes in skills and competences. In actuality, various age stereotypes are negatively colored. For instance, it is assumed by people that older individuals are flexible, reluctant to change and underperform (Kite, Stockdale, Whitley, \& Johnson, 2005). In spite of the prevalence of the negative age stereotype against older people, younger employees are not left out as they are assumed to lack patience, social competence and experiences (Schlick, Frieling, \& Wegge, 2013).

\section{Employee Performance}

Durga (2017) defined performance as the act of executing a task or an accomplishment or achievement. He adds that employee performance is how well an employee is effectively fulfilling his/ her job requirement or discharging his/ her duties so as to achieve good results. O'Flynn, et al. (2001) citing William and O'Reilly (1998) said employee performance is defined using three criteria. First criteria, is that employees' output meets the standard of performance set by the organization's external customers. Secondly, employee performance can be defined in terms of how the social processes utilized in the performance of their jobs enhances or maintain the capability of the employees to work together on subsequent group tasks. Finally, that employee's personal needs are satisfied instead of them being frustrated by the group performance. O'Flynn, et al. (2001) citing Ancona (1992) argue that there are multiple dimensions when it comes to rating of performance seeing that different constituents have their different performance criteria and access to data. For instance, management may be more interested in looking at the output of the employees whereas; the employees make be interested in creating a productive environment for themselves. Information and decision making theory predict that a positive outcome exist between employee performance in intellectual and complex tasks and information as employees have diverse knowledge, skills, experience and expertise which results in innovation, new product design and improved decision making.

\section{Public Universities in Kenya}

Public universities in Kenya are charged with the responsibility of providing higher education to all in the country on a competitive yet balanced basis accounting for $80 \%$ of the total university students' enrolment in the country. The universities were previously established under individual Acts of Parliament until the enactment of Universities Act No. 42 of 2012 which saw all individual Acts repealed and public universities re-accredited through charter award after institutional quality 
audits. All public universities in Kenya operate under the oversight of Commission for University Education (CUE) to which they are accredited a move aimed at promoting, regulating, monitoring and dealing with all matters related to university education. Currently there are 22 fully accredited public universities and 9 constituent colleges (CUE, 2013).

The public universities are in different geographical locations in the country and are autonomous in matters of management of their human resources. All public universities major funding is by the government and their core activities is teaching, research and consultancy services. Being public establishments, public universities are also affected by legislations and government directives that are deemed to be of national interest and best human resource practices (Nguata, 2013). This forms a ground for investigating the relationship between age diversity and employee performance of these establishments and how this is moderated by the organization culture of each individual institution.

\section{Statement of the Problem}

The world's increasing globalization needs more interaction between people from diverse cultures, thinking, and backgrounds than in the past (Green et al., 2002). Considering that the world economy is now globalized and more culturally diverse, these multicultural work forces are making work environment different from traditional one (Mazur, 2010). Thomas (1990) pointed out that corporate competence counts more than ever, and today's nonhierarchical, flexible, collaborative management requires an increase in tolerance for individuality. The question is not, therefore, one of accepting that individuals are different but creating an atmosphere of inclusion and making a commitment to valuing diversity. Research suggests that managers should actively manage and value workforce diversity because if designed and implemented properly, effective diversity management practices can support key organizational development initiatives (Storey, 1999).

In Kenya vision 2030- a new development blueprint which aims to transform Kenya into a middleincome country, intends to create a globally competitive and adaptive human resource base that will meet the requirement of the country (Government of Kenya, 2007). Its potential lies in the people's creativity, work ethics, education, and entrepreneurial skills based on human resource practices of well qualified and flexible personnel for effective competition in the global economy. This can only be achieved through effective management of public universities as the main source of future labour force because they account for 80 percent of the total students' enrollment in higher institutions of learning (Kenya National Bureau of Statistics, 2014). Despite government legislations that have been put in place to ensure workforce diversity in public establishments, questions have been raised regarding workforce diversity in public universities in Kenya. In a report released by the National Cohesion and Integration Commission (2012), it indicated that most of the public universities in Kenya still have major issues relating to age, ethnic, regional, educational and racial inclusion. There is therefore need for these institutions to rapidly adopt workforce diversity management practices in the context of their organization culture to achieve this objective.

Several studies have been conducted on the benefits of diversity to organizations. In a research on Workforce Diversity Management and Employee Performance in the Banking Sector in Kenya by Munjuri \& Maina (2013), it was found out that cultural diversity management seems more sensitive in the Bank and served a pivotal role. It encourages better employee retention, increased productivity, better morale, an expanded market share and improved customer service while a study 
by Kundu (2001) in his research on Managing Cross Cultural Diversity concluded that organizations with high levels of well managed diversity are effective in steering corporate cultures that have new perspectives, pioneering capabilities and fresh ideas necessary to survive. However, despite several studies that have been conducted on workforce diversity, there still exists a gap in determining the relationship between workforce diversity specifically; age diversity and employee performance in public universities in Western Kenya.

\section{LITERATURE REVIEW}

\section{Theoretical Framework}

Workforce diversity is a very broad field which arguably, has been generalized across many boundaries. That is, management research, functional categories, social categories and psychological research. Diversity theorists have recently turned to the well-established field of social psychology for insights into how diversity affects individuals and groups in organizations. Social psychologists have examined the processes involved with social identity and intergroup relations and diversity scholars recognized that this research tradition can provide a solid background for emerging theories on workplace diversity. Organizational researchers often refer to inborn human characteristics as dimensions of diversity, or social category diversity. The theoretical foundations for primary dimensions of diversity include the self-categorization theory (Turner, 1982), the social identity theory (Tajfel, 1978), the similarity paradigm theory (Thatcher, 1999), and the racial identity theory (Jehn, 1999). These theories describe how people react to observable demographic characteristics. The primary dimensions of diversity shape people's perception and behavior without regard to worktask relevance. According to O'Flynn, Ricciotti, Nicholas, Lau, Sammaritino, \& Fisher (2001) the three most commonly used theories of diversity are the social categorization theory, the similarity attraction paradigm and the informational diversity and decision making perspective.

\section{Empirical Review}

\section{Age Diversity}

According to Winnie (2008), youngsters who are at their learning stage are more willing to learn new things and accept new ideas. Older people who have more life experiences are more mature and possess better problem solving skills. As an addition, she also states that the western findings suggested that the older and younger employees must come together to form coherent and viable corporate culture. These values possessed by different age groups can complement each other in companies and it tends to achieve better firm performance. In her study, result shows that different age groups provide different values for companies and these values can complement each other which improves employee performance. However, Gellner and Veen, (2009) argues that age heterogeneity on its own has a negative effect on individual productivity. Moreover, in the case of routine tasks, there are no substantial gains from age heterogeneity that could offset the increasing costs resulting from greater age heterogeneity. Thus, in companies with routine types of work, increasing age heterogeneity overall leads to a decline in productivity Similarly, Joshi and Jackson, 2008; found no main effect of age diversity on employee reports of team processes or objectives measure of team performance. 
Growing age diversity has become part of many organizations (Florian Kunze, Stephen Boehm and Heike Bruch, 2009). There are two major theories which explain this relationship; the social identity and self-categorization theories. Individuals are suggested to classify themselves into certain groups on the basis of dimensions that are personally relevant for them according to social identity and selfcategorization theory (Kunze, Boehm and Bruch, 2009; Tajfel and Turner, 1986). As a result, individuals tend to favor members of their own group at the expenses of the other groups, against which they may discriminate. Consequently, if the employees' age or generational belonging is regarded as a relevant criterion for distinction, a differentiation between age groups within an organization may emerge, fostering emotional conflicts and age based discrimination between the age groups (Kunze et al., 2009).

Gelner and Stephen (2009) summarized that age heterogeneity can negatively affect productivity concerns differences in the values in and preferences of distinct age groups. It has been shown that productivity diminishing conflicts are particularly frequent in the presence of "generation gaps" (Gelner and Stephen, 2009; Lau, Murnighan, 2005; Pitcher, Smith 2001). However, Gelner and Stephen (2009) also include that age heterogeneity may be placed in proximity with its potential benefits. Complimentarily effects emerge when collaboration in a group enables individuals to be more productive than when working on their own. Hence, the benefits of age heterogeneity are based on additional productivity effects that arise due to interaction among individuals of different ages with differing skill profiles, differing perspectives and perhaps also different personality traits. Lastly, according to Brown (2008), increased diversity may also provide many challenges for human resource management, as the workforce ages, for instance, employers will have to struggle with higher healthcare costs and pension contributions. Employees will need to accept that benefits are in sync with the vision of the organization; thus, their commitment will increase substantially.

\section{Age Diversity and Employee Performance}

Kunze, Boehm and Bruch (2013) drawing from social-identity and social categorization theory, they theoretically argue that, in age-diverse companies, age-based subgrouping processes occur, favoring a shared perception of a negative age-discrimination climate. This perceived negative agediscrimination climate in turn negatively relates to organizational performance. As the main contribution, top managers' negative age-related stereotypes and diversity-friendly HR policies are introduced as organizational-level moderators that increase and attenuate, respectively, the social categorization processes affecting performance in age-diverse companies. They utilized structural equation modelling (SEM) to test the proposed hypotheses using a multisource dataset comprising 147 companies. The results supported all hypotheses, indicating that low negative top managers' age stereotypes as well as high diversity-friendly HR policies are potential organizational factors that can prevent the negative relation of age diversity with organizational performance transmitted through the negative age-discrimination climate. They recommend the result to be discussed in light of their contribution to the diversity literature and social-categorization theory as well as their implication for practitioners.

Darwin (2015) in his study on age diversity and its impact on employee performance in Singapore, identified age as one of the strategic capabilities that will add value to organizations over their competitors. The study focused on the perception of employees about the effect of the age diversity 
in their organizations. A self-administered questionnaire was used to collect the views of employees in both manufacturing and service industries in Singapore. The Cronbach's alpha value of the survey was 0.708 . The empirical relationship of age of the employees with the organizational performance was computed using SPSS package. The analysis revealed that there is a negative relationship between age group of employees and their performance. The study concluded that organization culture, human resource practices, nature of work and business strategy of individual firms are different from each other and the differences are likely to mask the impact of variables on the employee performance in one firm with that observed in another firm.

Fidan (2011) study on the consequences of grouping workers into diverse divisions on the performance of employees using a dataset containing the detailed personnel records of a large U.S. firm from 1989-1994. The study particularly examined the effects of demographic dissimilarity among co-workers, namely differences in age, gender and race among employees who work together within divisions, and non-demographic dissimilarity, namely differences in education, work function, firm tenure, division tenure, performance and wages among employees within divisions. The study found out that age dissimilarity, dissimilarity in firm tenure, and performance dissimilarity are associated with lower worker performance, while wage differences are associated with higher worker performance. It also reveals that the effects of certain types of dissimilarities get smaller in magnitude the longer a worker is a part of a division. Finally, the study provides evidence that the relationships between performance and the various measures of dissimilarity vary by occupational area and division size.

Zhuwao (2017) in the study to investigate the effects of workforce diversity on employee performance in a selected higher educational institution in South Africa argues that various legislative measures were introduced by the government in order to shape the workforce in organizations. However, these legislative measures expressly focus on compelling organizations to embrace diversity and thus not considering the business need of it and how it influences employee behavioral outcomes such as employee performance. It is upon this backdrop that the study investigated the effects of workforce diversity on employee performance. A cross-sectional research design was used and a random sample $(n=267)$ was chosen by dividing employees into homogeneous strata of academic and non-academic employees. A Workforce Diversity Questionnaire and Employee Work Performance Questionnaire were administered. The results showed a positive and significant relationship between independent variables (gender diversity, ethnic diversity and educational diversity) and the dependent variable (employee performance). The relationship between age diversity and employee performance was not significant.

Fabian (2015) in his study on the influence of top management team diversity on academic excellence in universities, applied the upper echelon theory to universities and three hypotheses were developed: (overall) top management team heterogeneity is positively associated with successful funding of excellence clusters, (overall) top management team heterogeneity is positively associated with successful funding of graduate schools and (overall) top management team heterogeneity is positively associated with academic reputation. The empirical study was based on a cross-sectional dataset with a time lag, covering characteristics of 75 German public universities from 2008 to 2013. Multiple-regression analysis was applied to test the hypotheses. The results indicating 
INTERNATIONAL JOURNAL OF ACADEMIC RESEARCH IN BUSINESS AND SOCIAL SCIENCES

Vol. 8, No. 11, Nov, 2018, E-ISSN: 2222-6990 @ 2018 HRMARS

that disciplinary and educational diversity of upper echelons has a positive effect on the outcomes. Other top management team characteristics (age, gender, etc.) show no significant effects.

\section{RESEARCH METHODOLOGY \\ Research Design}

The study used mixed method design which includes the use of more than one method of data collection in a research study, mixing qualitative and quantitative data (Creswell \& Plano Clark, 2007). Using triangulation or greater validity, quantitative and qualitative data will be converged in order for the findings to be mutually corroborated (Greene, 2007). Mixed method design was appropriate for this study because it allowed collection of information for independent and dependent variables using open and closed ended questions. Qualitative approaches enables collection of data in form of words rather than numbers. It provides verbal descriptions rather than numerical (Kothari, 2009). According to Mugenda and Mugenda (2003), qualitative methods can be used to gain more in depth information that may be difficult to convey quantitatively. Quantitative approach on the other hand strives for precision by focusing on items that can be counted into predetermined categories and subjected to statistical analysis (Johnson \& Christensen, 2014).

\section{Target Population}

Mugenda and Mugenda (2003) assert that, the target population is the population to which a researcher wants to generalize the results of the study. The target population of this study was the public universities in Kenya. The sample consisted of four public universities namely: Maseno University, Masinde Muliro University of Science and Technology, Jaramogi Oginga Odinga University of Science and Technology and Kisii University. The respondents were 120 head of departments working in these universities. The head of departments were selected because they are the apex of decision making in the respective departments, from the four respective universities.

\section{Sample Size and Sampling Procedures}

A sample size is the number of subjects that should be studied and from which reliable inferences can be made about a population. The sample frame for this study included head of departments in administrative, teaching and non-teaching staff of all fully accredited public universities by 2014 in Western Kenya region. The study targeted all 120 head of departments from the respective universities who gave information that best answered the research questions. Sampling is the process of selecting few cases from a target population in order to provide information that can be used to make judgments about a much larger number of cases (Kothari, 2004). A census of all the head of departments from the four universities in Western Kenya was adopted. A census enables a complete enumeration of all items in the population (Oso \& Onen, 2006). According to Saunders, Lewis and Thornhill (2007) this is an attempt to collect data from every member of the population being studied rather than choosing a section.

\section{Pilot Testing of the Instrument}

Pilot study is defined as a small-scale test of the methods and procedures to be used on a large scale (Porta, 2008). The Researcher carried out the pilot testing of the questionnaire for validity and 
reliability on a small and similar group to the one that was used in the research in Maseno University. The process of pilot testing used convenience sampling where members of the population were chosen based on their relative ease of access (Lucas, 2014) and respondents who volunteer give an advantage of time and large proportion of the population can be used (Wiederman, 1999). A sample size of twelve (12) participants was used in the pilot study which is $10 \%$ of the sample size of 120 respondents for the actual study. Baker (1994) found out that a sample size of $10 \%$ of the sample size for the actual study is a reasonable number of participants to consider enrolling in a pilot study. Pretesting the questionnaire was important because: ambiguous and vague questions were revealed as respondents interpreted them differently; comments and suggestions made by the respondents were used to improve the questionnaire; deficiencies in questionnaire were revealed and in pilot study researcher analyzed the questionnaires to see if the methods of analysis were appropriate. Fink and Kosekoff (1985) suggested that when pilot-testing the questionnaire look out for failure to answer questions, respondents giving several answers to the same question and written comments; these maybe indicators that the instrument is unreliable and needs revision. The questionnaire which incorporated all the suggestions observed was again pre-tested by the researcher on another similar group to confirm its validity and reliability. The researcher accepted the instrument as suitable for the research once it met the set conditions.

\section{Validity of the Instruments}

Construct validity is the degree to which a test measures what it claims, or purports, to be measuring. Content validity on the other hand refers to the extent to which a measure represents all facets of a given subject area. Validity therefore refers to the extent to which an empirical measure adequately reflects the real meaning of the variables under investigation (Wilson, Pan and Schumsky, 2012). In ensuring validity of the instruments, an analysis was done on the study variables and linked them on the test construct by a group of knowledgeable and experienced researchers. Appropriateness of the questions was tested by content validity ratios( CVR) by the subject matter expert raters (SMEs) and the mean CVR across items was used as an indicator of overall test content validity (Lawshe, 1975).

\section{Reliability of the Instruments}

Reliability is the degree to which a measurement technique can be depended upon to secure consistent results upon repeated application. Reliability can be internal or external. Internal reliability is the extent to which data collection, analysis and interpretation are consistent. If multiple data collectors are used, they should agree. External reliability is the extent to which the results can be replicated. The internal consistency method provides a unique estimate of reliability for the given test administration. There are four common ways of estimating reliability: the test - retest method, the parallel (equivalent) - form technique, the split - half method and the internal consistency. The researcher used the split-half reliability test and calculated the reliability of the questionnaire using the Cronbach's Coefficient Alpha. The most popular internal consistency reliability estimate is given by Cronbach's alpha which is usually interpreted as the mean of all possible split-half coefficients (Willmott \& Nuttall, 1975). Using the correlation matrix alpha the following equation is used; $\boldsymbol{\alpha}=\mathbf{N P}$ / $[1+\mathrm{P}(\mathrm{N}+1)]$

Where $\mathbf{N}$ equals the number of items and $\mathbf{p}$ equals the mean interim correlation. 
The instrument testing reliability used different numbers of scale items in each variable. The study tested reliability of age diversity (independent), employee performance (dependent) and organization culture (moderating) variables. A Cronbach's alpha coefficient of 0.7 and above was considered high enough to judge the instrument as reliable. A high Cronbach's alpha coefficient implied that the items correlated highly among themselves, that is, there was consistency among the items in measuring the concept of interest (Mugenda\& Mugenda 2003). A test-re-test coefficient of 0.904 was achieved and considered desirable. This is consistent with the proposition of Mugenda (2010) that, the higher the test-re-test coefficient, the better the test-re-test reliability, hence the stability of the measure across time.

\section{Data Processing and Analysis Techniques}

Data analysis was conducted according to the research objectives and hypotheses. This included the need to establish the relationship between age diversity and employee performance of public universities in the Western region of Kenya. Before processing the responses, data preparation was done on the completed questionnaires by editing, coding, entering and cleaning the data. Data collected was analyzed by descriptive and inferential statistics. Descriptive statistics was used to summarize the survey data and provide immediate summary statistics for the various objectives. These included measures of central tendency and measures of relationships. In particular, Regression Analysis was used to investigate the relationship(s) that had been hypothesized amongst the variables of study. As espoused by Mugenda and Mugenda (2003) correlation technique was used to analyze the degree of relationship between the variables. Content analysis was also conducted on the data that are of qualitative nature. In conventional terms, content analysis involves description and discussion of the data. Results were presented in tables.

\section{FINDINGS AND DISCUSSIONS}

\section{Response Rate}

A total of 120 questionnaires were distributed to the head of sections/department of the target population. The population consisted of four public universities namely: Masinde Muliro University of Science and Technology, Maseno University, Jaramogi Oginga Odinga University of Science and Technology and Kisii University. Those respondents who filled and returned usable questionnaires were 93 making a response rate of $78 \%$. The $22 \%$ of the respondents failed to fill the questionnaires even after several follow up or filled them badly making them unusable. This response rate was in line with previous researches. According to Mugenda and Mugenda (2003), a response rate of $50 \%$ is adequate for analysis and reporting; a rate of $60 \%$ is good and a response rate of $70 \%$ and over is excellent. This meant that the response rate of $78 \%$ was excellent and therefore enough for the study to proceed to the data analysis, presentation, interpretation and discussion.

\section{Bio Data}

The study was interested in the background information of the respondents in the areas of the position held by the responded in the organization, age, highest level of education and length of service of the responded with the organization in order to determine whether the respondents were capable of interpreting the information in relation to its implication on employee performance in 
INTERNATIONAL JOURNAL OF ACADEMIC RESEARCH IN BUSINESS AND SOCIAL SCIENCES

Vol. 8, No. 11, Nov, 2018, E-ISSN: 2222-6990 @ 2018 HRMARS

public universities in Western Kenya.

\section{Distribution of Respondents by Age}

The study sought to determine the age distribution of the respondents in order to gauge their work experience, loss of skills due to retirement, institutional memory and employee succession. The rate of loss or retention of these factors has an impact on employee performance in public universities. High percentage of young people means the organization lacks experienced people but is well endowed with energetic people to drive the company forward. High percentage of old staffs mean that the organization lacks energetic staff to drive its mission and also the organization will lose experienced people at once which may lead to lose of many experienced people and institutional memory. The study found out that 28(30.1\%) of the respondents were aged above 55 years, 23(24.7\%) were aged between 49 to 53 years, $17(18.3 \%)$ were aged between 43 to 48 years, $17(18.3 \%)$ were aged between 37 to 42 years, 8(8.6\%) were aged between 31 to 36 years and none of the respondents was below 30 years. The population of head of departments was well distributed and all age groups were adequately represented. According to Winnie (2008), youngsters who are their learning stage are more willing to learn new things and accept new ideas. Older people who have more life experiences are more mature and possess better problem solving skills. As an addition, the researcher also stated that the values possessed by different age groups can complement each other in companies and this tends to achieve better firm performance.

\section{Distribution of Respondents by Gender}

The study sought to determine the gender distribution of the respondents and found out that $67(72 \%)$ were male while $26(28 \%)$ were female. This study therefore reveals that despite majority of the head of departments in public universities being of male gender the female gender constitute $28 \%$. This is approximately one third of all the head of departments and hence meeting the threshold of the legal requirements. Moreover, this representation is adequate to bring in diversity and therefore answer the research question on gender diversity and employee performance in public university. According to Emiki \& Eunmi (2009), significant amount of workforce diversity remains ineffective if gender issues are not first recognized and managed. The research and study also state that the most constitutional challenge is overcoming the thought that woman are not equal to man.

\section{Distribution of Respondents by Highest Level of Education}

The study also sought to determine the educational level of the respondents. The results show that 55(59.1\%) are PhD holders, 21(22.6\%) have Master's degree, 8(8.6\%) have Bachelor's degree, 7(7.5\%) are diploma holders and $2(2.2 \%)$ have other qualifications like higher diploma and post graduate certificate. The education level of the respondents was ideal because the respondents could read, interpret and answer questionnaires appropriately. The study indicated that majority of the respondents had a PhD degree based on the fact that the study was carried out in institutions of higher learning and the target respondents were head of departments in these organizations. Cagle (1988) has regarded experience and education as factor that determine the leadership style and employee performance. Katozai (2005) argued that knowledge is a chief weapon that makes a person effective as a leader and therefore a leader should be educated, experienced and qualified. Nsubuga 
(2009) concluded that unless principals are well equipped with knowledge and skills in management and leadership, they would not be effective. This implies that for the public universities under study the head of departments are well educated and could steer employee performance in these organizations.

\section{Distribution of Respondents by Length of Service with the Organization}

The study sought to establish for how long the respondents have been working with the same organisation in order to gauge the level of skills acquired, work experience in the company and the institutional memory stored; The results show that $28(30.1 \%)$ of the respondents had worked for the organisation for more than 15 years, 39(41.9\%) had worked for their organization for 10 to 14 years, 17(18.2\%) had worked for 5 to 9 years, and 9(9.6\%) had worked for less than 5 years. The study show that out of the $93(100 \%)$ respondents, majority of the respondents $39(41.9 \%)$ had worked for the organizations for between 10 and 14 years which shows experienced employees with good understanding of the organizations' vision, mission, values and culture. According to Boxall (1998) the fundamental priority of HR strategy in a firm is to secure and maintain the kind of human resources that are necessary for the firm's viability. The labor turnover interferes with total employees' experience and working relationships built over the period of time.

\section{Age Diversity and Employee Performance of Public Universities}

The objective and null hypothesis the study was to achieve were; to determine relationship between age diversity and employee performance of public universities in Western Kenya, and $\mathbf{H}_{\mathbf{0 1}}$ : There is no statistically significant relationship between age diversity and employee performance of public universities in Western Kenya respectively. The study used both the primary and the secondary data and the descriptive statistics were used to analyze the data and interpretations made from them. Regression analysis, correlation analysis and hypothesis testing were used to establish the relationship between age diversity and employee performance in public universities in Western Kenya. The results are presented in sub- thematic areas.

\section{Descriptive Statistics}

The study examined Age Diversity indicators which were, age groups inclusion, mentoring and bonding in regard to how they influenced the employee performance of public universities in Western Kenya.

The research results are shown in Table 4.1 using a Likert scale of 1-5 where 5= Strongly Agree; 4=Agree; 3=Neutral; 2= Disagree; 1 = strongly disagree, $\mathrm{M}=$ Mean, $\mathrm{SD}=$ standard deviation and \% = Percentage of Respondents. 
INTERNATIONAL JOURNAL OF ACADEMIC RESEARCH IN BUSINESS AND SOCIAL SCIENCES

Vol. 8, No. 11, Nov, 2018, E-ISSN: 2222-6990 @ 2018 HRMARS

Table 4.1 Age Diversity

\begin{tabular}{|c|c|c|c|c|c|c|c|c|c|}
\hline $\begin{array}{l}S / N \\
S D\end{array}$ & \multicolumn{2}{|l|}{ Statement } & 1 & 2 & 3 & & 4 & 5 & $\mathbf{M}$ \\
\hline a) & $\begin{array}{l}\text { My organization gives equal opportunit } \\
1.09 \\
\text { for diversity training to different age gr }\end{array}$ & es $\%$ & 6.5 & 8.6 & 5. & & 7.0 & 22.6 & 3.81 \\
\hline b) & $\begin{array}{l}\text { Older staff mitigate friction in teams } \\
1.22\end{array}$ & $\%$ & 10.8 & 10.8 & 20. & & 39.8 & 18.3 & 3.44 \\
\hline c) & $\begin{array}{l}\text { The risk taken by younger employees } \\
1.02 \\
\text { contributes to team success }\end{array}$ & $\%$ & 6.5 & 4.3 & 31. & & 3.0 & 15.1 & 3.56 \\
\hline d) & $\begin{array}{l}\text { Different age groups are included in tea } \\
0.95\end{array}$ & m leadership & ip \% & 2.2 & 7.5 & 23.7 & 44.1 & 22.6 & 3.77 \\
\hline e) & $\begin{array}{l}\text { There is bonding among staff of differer } \\
0.89\end{array}$ & t age group & os \% & 2.2 & 5.4 & 21.5 & 51.6 & 19.4 & 3.80 \\
\hline f) & $\begin{array}{l}\text { Age differences causes conflicts in team } \\
0.85\end{array}$ & S $\quad \%$ & & 48.0 & 37.2 & 9.2 & 3.5 & 2.2 & 3.86 \\
\hline g) & $\begin{array}{l}\text { Mentoring by older staff benefits young } \\
0.96\end{array}$ & er staff & $\%$ & 4.3 & 7.5 & 16.1 & 57.0 & 15.1 & 3.71 \\
\hline h) & $\begin{array}{l}\text { I am positive about age diversity in my } \\
0.92\end{array}$ & vork place & $\%$ & 1.2 & 6.3 & 12.9 & 37.6 & 41.9 & 4.14 \\
\hline & Overall Mean & & & & & & 3.76 & 0.99 & \\
\hline
\end{tabular}

From table 4.1, results from Age diversity show that $57 \%$ of the respondents agreed that their organization gives equal employment opportunities for diversity training to different age groups with only $6.5 \%$ strongly disagreeing with this. The mean Likert item was 3.81 indicating that opportunities for diversity training to different age groups was practiced to a large extent in public universities. In addition $39.8 \%$ agreed that older employees mitigates friction within teams, with only $10.8 \%$ disagreeing and $10.8 \%$ strongly disagreeing. The mean item was 3.44 showing employees perceive this statement to a moderate extent. The result is in agreement with Scott \& Byrd (2012) findings that supports training and development to different age groups in a work place. The study argues that this enables all the management and employees to be aware of the elements of individual's difference among employees and how to accept, respect and value the similarities and differences among the workforce.

In addition, $43 \%$ of the respondents agreed that the risk taken by younger employees contributes to team success, with $31.2 \%$ remaining neutral while $6.5 \%$ strongly disagreeing. With a mean Likert item of 3.56 the respondents to a large extent agreed that the risk taken by younger employees contributes to team success in public universities. The findings supports Winnie (2008) study which found out that youngsters who are their learning stage are more willing to learn new things and accept new ideas which leads to improved performance in an organization.

The other indicator was on inclusion of different age group members in team leadership and the study results show that $44.1 \%$ agreed and $22.6 \%$ strongly agreed with this practice. The results further 
shows that only $9.7 \%$ cumulatively disagreed with $23.7 \%$ of the respondents remaining neutral on this statement. A mean of 3.77 indicating that to a large extent team leadership includes members of different age groups in public universities. These results are in agreement with Boehm and Kunze (2015) study which argued that an age heterogeneous workforce yields a host of multiple skills, intellectual styles, morals, and preferences that may result in increased productivity. This supports Park and Lin (2008) who outlined that the perceptions, cognitive models and interpretations of an age diverse workforce are different hence, if brought together may result in a larger pool of knowledge, a larger problem solving toolbox and increased employee performance.

Nevertheless, $51.6 \%$ agreed that there is bonding among staff of different age groups with $19.4 \%$ strongly agreeing. $21.5 \%$ of the respondents were neutral while $5.4 \%$ disagreeing and $2.2 \%$ strongly disagreeing. The mean was 3.80 indicating that to a large extent there is bonding among staff of different age groups in public universities. This findings corroborates with Winnie (2008) study which found out that youngsters who are their learning stage are more willing to learn new things and accept new ideas. Older people who have more life experiences are more mature and possess better problem solving skills.

Results of this study further show that cumulatively $85 \%$ disagrees that age difference causes conflicts among employees, with $9.2 \%$ choosing to remain neutral and $2.2 \%$ strongly agreeing. With mean of 3.86 the results indicate that to a large extent age difference does not cause conflict in public universities. This contradicts Erasmus (2007) study which argued that age diversity creates conflict and uncertainty in the workforce as management, on average. The study poses that employees still make decisions to break the rules and policies with their behavior when it comes to age diversity (Victoria and Mary, 2010).

Nevertheless, $57.0 \%$ of the respondents agreed and $15.1 \%$ strongly agreed that mentoring by older employees benefits younger employees in their organization. The results shows that $16.1 \%$ were neutral and cumulatively $11.8 \%$ disagreed. The mean of 3.71 shows that to a large extent mentoring by older employees' benefits younger employees in public universities. The results corroborates with Gilbert \& Ivancevich (2000) findings that it is essential for management to create a system of equal opportunity for all employees and ensure diversity management policies that would guarantee the maintenance of employees' competence so as to guard the organizations competitive position.

Finally, $37.6 \%$ of the respondents agreed that they are positive with the age diversity in their organization, and $41.9 \%$ of the respondents even strongly agreeing with the statement. $12.9 \%$ chose to remain neutral with cumulatively only $7.9 \%$ disagreeing. A mean of 4.14 showing that to a large extent employees in public universities are positive about age diversity. This findings agree with Bantel and Jackson (1989) study which found out that workgroup diversity is positively associated with creativity and problem-solving skills. 
INTERNATIONAL JOURNAL OF ACADEMIC RESEARCH IN BUSINESS AND SOCIAL SCIENCES

Vol. 8, No. 11, Nov, 2018, E-ISSN: 2222-6990 @ 2018 HRMARS

\section{Regression Analysis}

Table 4.2 Regression between Age Diversity and Employee Performance

\begin{tabular}{|c|c|c|c|c|c|c|c|c|}
\hline \multirow[t]{2}{*}{ Model } & \multicolumn{2}{|c|}{$\begin{array}{l}\text { Unstandardized } \\
\text { Coefficients }\end{array}$} & \multirow[t]{2}{*}{$\mathrm{T}$} & \multirow[t]{2}{*}{ Sig. } & \multicolumn{2}{|c|}{$\begin{array}{l}95.0 \% \text { Confidence } \\
\text { Interval for B }\end{array}$} & \multicolumn{2}{|c|}{$\begin{array}{l}\text { Collinearity } \\
\text { Statistics }\end{array}$} \\
\hline & B & $\begin{array}{l}\text { Std. } \\
\text { Error }\end{array}$ & & & $\begin{array}{l}\text { Lower } \\
\text { Bound }\end{array}$ & $\begin{array}{l}\text { Upper } \\
\text { Bound }\end{array}$ & Tolerance & VIF \\
\hline (Constant) & 9.734 & 2.207 & 4.410 & .000 & 5.350 & 14.117 & & \\
\hline Age Diversity & .333 & .072 & 4.615 & .000 & .189 & .476 & 1.000 & 1.000 \\
\hline
\end{tabular}

The regression model was as follows;

$\mathbf{Y}=9.734+0.333 \mathrm{X}+2.279$

A regression analysis was carried out and the findings show that there is a significant positive association between age diversity and employee performance. If age diversity increases by one unit, employee performance increases by 0.333 units. This is agreement to Gelner and Stephen (2009) findings that age heterogeneity may be placed in proximity with its potential benefits. They argue that complimentarily effects emerge when collaboration in an age diverse group enables individuals to be more productive than when working on their own. Hence, the benefits of age heterogeneity are based on additional productivity effects that arise due to interaction among individuals of different ages with differing skill profiles, differing perspectives and perhaps also different personality traits.

\section{Correlation Analysis}

Table 4.3 Correlation between Age Diversity and Employee Performance

\begin{tabular}{llrr}
\hline & & \multicolumn{1}{c}{$\begin{array}{c}\text { Age } \\
\text { Diversity }\end{array}$} & $\begin{array}{c}\text { Employee } \\
\text { Performance }\end{array}$ \\
\hline \multirow{3}{*}{ Age Diversity } & Pearson Correlation & 1 & $.436^{* *}$ \\
& Sig. (2-tailed) & & .000 \\
& $\mathrm{~N}$ & 93 & 93 \\
Employee Performance & Pearson Correlation & $.436^{* *}$ & 1 \\
& Sig. (2-tailed) & .000 & 93 \\
& $\mathrm{~N}$ & 93 & \\
\hline
\end{tabular}

**. Correlation is significant at the 0.01 level (2-tailed).

The objective the study was to achieve was to determine relationship between age diversity and employee performance of public universities in Western Kenya. A correlation analysis was carried out and it was established that there was a statistically significant moderate positive association between age diversity and employee performance in public universities in Western Kenya; $r=0.436, p<0.001$, 
INTERNATIONAL JOURNAL OF ACADEMIC RESEARCH IN BUSINESS AND SOCIAL SCIENCES

Vol. 8, No. 11, Nov, 2018, E-ISSN: 2222-6990 @ 2018 HRMARS

$\mathrm{CL}=95 \%$ (2-tailed). This means that when age diversity improves, then employee performance also improves in public universities in Western Kenya.

\section{Hypothesis Testing}

The null hypothesis of the study was;

$H_{0}$. There is no significant relationship between age diversity and employee performance in public universities in Western Kenya. The results are shown in table 4.4.

Table 4.4 Hypothesis testing on Age diversity and Employee performance.

ANOVA

\begin{tabular}{lcrccc|}
\hline & Sum of Squares & Df & Mean Square & F & Sig. \\
\hline Between Groups & 828.397 & 15 & 55.226 & 4.595 \\
0.000 & & & & \\
Within Groups & 925.410 & 77 & 12.018 & \\
Total & 1753.806 & 92 & & \\
\hline
\end{tabular}

The study tested the null hypothesis $\left(\mathrm{H}_{0}\right)$ that there is no significant relationship between age diversity and employee performance in public universities in Western Kenya. The $\mathrm{F}$ distribution table gave a reading of critical value $=2.90$ and $F(15,77)=4.595,2.90<4.595$, because the calculated value is greater than the critical value, therefore we reject the null hypothesis, this means that it is statistically very unlikely that the null hypothesis $\left(H_{0}\right)$ is true. We revert to the alternative hypothesis $\left(H_{1}\right)$ that there is a significant relationship between age diversity and employee performance in public universities in Western Kenya. The results corroborates with Parrotta, Pozzoli and Pytlikova (2011) studies on the impact of age diversity in firms which found out that a diverse workforce in terms of age has benefits in terms of production of quality products and services. They postulate that the younger employees bring their knowledge of Information Technology (IT) while older employees bring their better understanding of the market dynamics to generate products and services that are of high quality, which capture the intended market.

\section{Employee Performance}

Employee performance in public universities in Western Kenya is very critical because it determines whether they are to achieve their objectives or not. Employee performance also tends to enhance their corporate image. The study, therefore, sought to measure the extent to which employee performance contributes to achievement of organizational objectives in public universities in Western Kenya. The study used both the primary and the secondary data and the descriptive statistics were used to analyze the data and interpretations made from them. Regression analysis was used to establish the relationships between various variables. The results are presented in sub- thematic areas. 
INTERNATIONAL JOURNAL OF ACADEMIC RESEARCH IN BUSINESS AND SOCIAL SCIENCES

Vol. 8, No. 11, Nov, 2018, E-ISSN: 2222-6990 @ 2018 HRMARS

\section{Descriptive Statistics}

The research results are shown in Table 4.5 using a Likert scale of 1-5 where $5=$ Strongly Agree; 4=Agree; 3=Neutral; $2=$ Disagree; 1 = strongly disagree, $\mathrm{M}=$ Mean, $\mathrm{SD}=$ standard deviation and $\%=$ Percentage of Respondents.

Table 4.5 Employee Performance

\begin{tabular}{|c|c|c|c|c|c|c|c|}
\hline $\begin{array}{l}S / N \\
S D\end{array}$ & Statement & 1 & 2 & & 3 & 5 & $\mathbf{M}$ \\
\hline a) & $\begin{array}{l}\text { Employees in the organization achieve their specified targe } \\
3.80 \quad 1.07\end{array}$ & $\mathrm{~s} \%$ & 4.3 & 7.5 & 20.4 & 39.8 & 28.0 \\
\hline b) & $\begin{array}{l}\text { The work performed by employees is of high quality } \\
34.4 \quad 3.970 .98\end{array}$ & $\%$ & & 2 & 5.4 & 20.4 & 37.6 \\
\hline c) & $\begin{array}{l}\text { Employees complete their work in accordance to time set } \\
3.921 .03\end{array}$ & $\%$ & 2.2 & 7.5 & 21.5 & 33.3 & 35.5 \\
\hline d) & $\begin{array}{l}\text { Employees optimize resources to get maximum results } \\
35.5 \quad 3.92 \quad 1.15\end{array}$ & $\%$ & & .5 & 4.3 & 11.8 & 40.9 \\
\hline e) & $\begin{array}{l}\text { The employees in the organization are creative } \\
4.130 .87 \\
\text { and innovative }\end{array}$ & $\%$ & 2.2 & 2.2 & 12.9 & 46.2 & 36.6 \\
\hline & Overall Mean and SD & & & & & 1.01 & \\
\hline
\end{tabular}

The study sought information on employee performance and results from table 4.5 show that a total of $67.8 \%$ of the respondents agreed while $7.6 \%$ disagreed on the first item which was on employees in the organization being able to achieve their specified targets. $20.4 \%$ of the respondents were neutral and the mean value was 3.80 indicating that to a large extent employees in public universities achieve their specified targets. This is supported by studies conducted by Connell et al., (2003) who sought to establish factors leading to successful performance of organizations. The study revealed that organizations are able to do better if their employees are focused and perform their tasks as expected of them. They argue that for this to happen, they (employees) must achieve their specified targets. Costa (2001) indicate that the level of organizations' profitability depends on how much their employees are able to achieve their specified targets.

In addition, the study sought information on the quality of the work performed by the employees. The results of the research reveal that a total of $72 \%$ of the respondents agreed while $7.6 \%$ disagreed. $20.4 \%$ of the respondents were neutral and the mean value for this item was 3.97 showing that to a large extent the work performed by employees in public universities is of high quality. The findings of this study are a true reflection of the studies conducted by Kraut and Kormon (2000) who sought to establish factors influencing successful performance of organizations in the agricultural sector in parts of Germany. The study revealed that the basis for successful performance is the expectation that employees will perform above expectations. Chani and Fullenkamp (2002) argue that an 
INTERNATIONAL JOURNAL OF ACADEMIC RESEARCH IN BUSINESS AND SOCIAL SCIENCES Vol. 8, No. 11, Nov, 2018, E-ISSN: 2222-6990 @ 2018 HRMARS

organization cannot achieve its objectives if the quality of work is low. Kaser and Miles (2002) also indicate that organizations should focus on quality of work rather than quantity. The same sentiments are also shared by Dirks (2000), Bolman and Deal (2003) and Sharkie (2005).

Nevertheless, the study also sought information on employees' completing their work in accordance to the time set. Results of the study reveal that a total of $68.8 \%$ of the respondents agreed while $9.7 \%$ disagreed with the statement. $21.5 \%$ of the respondents were neutral and the mean of the item was 3.92 revealing that to a large extent employees in public universities complete their work in accordance to the time set. The results of this study corroborate studies conducted by Cornelius (2010) who sought to establish the indicators of employee performance in an organization. The study revealed that accomplishing the assigned roles on time played a major role. Torlak and Koc (2007) indicate that organizations can achieve their objectives if only they set their priorities right and meet the expected threshold on time. Bell (2000) and Sharkie (2005) also argue that most organizations would like to retain employees who achieve their targets on time.

The study also sought information on the ability of employees to optimize resources to maximize on results and the study results show that cumulatively $76.4 \%$ of the respondents agreed while $11.8 \%$ disagreed. $11.8 \%$ of the respondents were neutral on this item and the mean value of 3.92 revealing that to a large extent employees in public universities optimize resources to maximize results. The results support Salihu, Salihu, and Musa (2016) study which examined the impact of organizational culture on employee performance in Nigeria. Ordinary least square (OLS) simple regression method of analysis was employed to examine the extent to which Employee Involvement, Consistency, and Organizational Mission, has impacted on Job efficiency, Job effectiveness, Job productivity. Findings from study revealed that Consistency as a factor of organizational culture was found to be a significant predictor of job efficiency. Organizations mission was also found to have a significant impact on Job efficiency in Nigeria.

The last item on employee performance sought information on the level of employees' creativity and innovativeness. The study results reveal that a total of $82.8 \%$ of the respondents agreed while only $4.4 \%$ disagreed with the statement. In addition, $12.9 \%$ of the respondents were neutral and the mean value of 4.13 was realized showing that to a large extent employees in public universities have high level of creativity and innovativeness. The results of this study are true reflection of the studies conducted by Kruse et al., (2010) who sought to investigate factors influencing employee productivity in an organization. The study revealed that creativity among other factors played a major role in employee productivity. Curme and Stefanec (2007) argue that employees who are creative and innovative are able to steer their respective organizations to greater heights of prosperity. Geddes and Heywood (2003) also indicate that organizations should encourage their employees to be creative and innovative if they have to achieve their goals. 
INTERNATIONAL JOURNAL OF ACADEMIC RESEARCH IN BUSINESS AND SOCIAL SCIENCES

Vol. 8, No. 11, Nov, 2018, E-ISSN: 2222-6990 @ 2018 HRMARS

\section{Conclusion}

Age diversity is very critical and positively influences employee performance in public universities in Western Kenya as indicated by the regression, correlation and hypothesis testing models. There is a statistically significant moderate positive association between age diversity and employee performance. Majority of the employees in public university are positive about age diversity initiatives and age difference does not cause conflict in this institutions. In addition, there is equal opportunities for training and development for employees in different age groups. However, public universities should strive to recognize younger employees in team success this is because majority of the team leaders are experienced and mature employee and much of the recognition for team success goes to them. Moreover, age diversity creates a situation in which generational skills, knowledge and experiences are harnessed in the production process ending the production of good and quality products. Alesina and La Ferrara (2005) share a similar sentiment arguing that workforce that is heterogeneous in age, precipitates more creativity and productivity which ultimately translates into better goods and serves as well as increased productivity of the firm.

The variables of this research were subjected to deeper statistical analysis and the findings and recommendations of the study offers help to the management in policy formulation and suitable choice of human resource diversity management practices that will enhance employee performance. This research further contributes into the existing knowledge in human resource and general management practices by validating the social identity and self-categorization theory, attraction selection and attrition theory, behavior engineering model and the theory of organization culture and effectiveness. It examines the relative magnitude of importance placed upon the organization workforce diversity toward attaining the improved performance of employees. The research also contributes to the literature by offering further understanding of the mentioned theories in the context of public universities therefore opening up this area for further research.

\section{Recommendations}

Public universities should come up with motivation programs that recognize younger employees in team success this is because majority of the team leaders are experienced and mature employees and much of the recognition for team success goes to them. The study further recommends that future studies on workforce diversity be undertaken and extend the scope by including other workforce diversity variables not covered in this study. Since the study concentrated on public universities, there is also need to undertake similar studies in private and other public sector institutions.

\section{References}

Ahmed, G.G. \& Wario G. (2013). Investigation of the Diversity Management Practices in the Civil Service in Kenya. International journal of innovative research and development, Vol 2; 11.

Armstrong, M. (2006). Human resource management (10th Ed.). London: Kogan Page. 
INTERNATIONAL JOURNAL OF ACADEMIC RESEARCH IN BUSINESS AND SOCIAL SCIENCES

Vol. 8, No. 11, Nov, 2018, E-ISSN: 2222-6990 @ 2018 HRMARS

Becker, G. (1964) Human Capital, Princeton, N.J. Princeton University Press.

Bennington, L. (2004). Prime Age Recruitment: The Challenges for Age Discrimination Legislation, Elder Law Review, Vol. 3.

Brown, S. L. (2008). Diversity in the Workplace: A Study of Gender, Race, Age, and Salary Level. Academy of Management Journal, 44(3), 533-545.

Carrel, M. R. (2006). Defining Workforce Diversity Programs and Practices in Organizations: A Longitudinal Study. Labor Law Journal. Spring, 2006.

Commission of University Education in Kenya. (2013). Status of Universities; Universities authorized to operate in Kenya.

Cox, T. (2001). Creating the Multicultural Organization: A Strategy for Capturing the Power of Diversity, San Francisco: Jossey-Bass.

Creswell, J.W. (2003). Research design: Qualitative, quantitative, and mixed methods approaches. (2nd Ed.) Thousand Oaks: Sage.

Creswell, J. W. \& Plano Clark, V. (2007). Designing and Conducting Mixed Methods Research. Thousand Oaks, CA.: Sage.

De Cieri, H. \& Kramar, R. (2003). Human resource management in Australia. Sydney: McGraw Hill.

Dimba, B.A. \& Rugimbana, R. (2013). An assessment of the moderating role of employees' cultural orientations amongst foreign manufacturing multinational companies in Kenya. SA Journal of Human Resource Management/SA Tydskrif vir Menslikehulpbronbestuur, 11(1).

D'Netto, B., Monga, M., Shen, J., \& Chelliah, J. (2008). Manufacturing Employees' Perceptions of Human Resource Diversity Management Practices in Australia. Sydney, Australia: The Australian Workers' Union.

D'Netto, B., \& Sohal, A. S. (1999). Human resource practices and workforce diversity: an empirical assessment. International Journal of Manpower, 20, 530-547

Emiko, M. \& Eunmi, C. (2009). Diversity management and the effects on employees' organizational commitment: Evidence from Japan and Korea. Journal of World Business, $44,31-40$

Erasmus. L. (2007). The management of workforce diversity and the implications for leadership at financial asset services. Retrieved from https://ujdigispace.uj.ac.za/handle/10210/356 
INTERNATIONAL JOURNAL OF ACADEMIC RESEARCH IN BUSINESS AND SOCIAL SCIENCES Vol. 8, No. 11, Nov, 2018, E-ISSN: 2222-6990 @ 2018 HRMARS

Gellner, K. \& Veen, S. (2009). The Impact of Aging and Age Diversity on Company Performance. Academy of Management Executive, 14 (1), 93-105.

Government of Kenya. (2007). Vision 2030, Ministry of planning and National Development and the National Economic and Social Council (NESC), Office of the President.

Green, K., López, M., Wysocki, A. \& Kepner, K. (2002). Diversity in the Workplace: Benefits, Challenges, and the Required Managerial Tools. University of Florida, USA.

Greene. J. C., Benjamin, L. \& Goodyear, L. (2001). The merits of mixing methods in evaluation. Evaluation, $7(1), 25-44$.

Harish, J. \& John, L. (2001). "Visible Minorities under the Canadian Employment Equity Act (19871999): An Analysis of Company Annual Report Data with Policy Recommendations," submitted to Heritage Canada (an agency of the Canadian Federal Government), December, 2001.

Inmyxai, S. \& Takahashi Y. (2010). Performance Comparison Derived from Human Resources between Male and Female Headed Firms in the Lao MSMEs. International Review of Business Research Papers, 6(2), 12-38.

Jabbour, C. J. C., Gordono, F. S., Oliveira, J. H. C. d., Martinez, J. C., \& Battistelle, R. A. G. (2011). Diversity management Challenges, benefits, and the role of human resource management in Brazilian organizations. Equality Diversity and Inclusion: An International Journal of Diversity in Organizations, Communities and Nations, 30, 58-74.

Jackson, B. W., LaFasto, F., Schultz, H. G. \& Kelly, D. (1992). Diversity; Human Resource Management, Vol. 31, No.1.

Jain, H. \& Verma, A. (1996). Managing workforce diversity for competitiveness: the Canadian experience. International Journal of Manpower, Vol.17, No. 4/5. Pp4-29.

Johnson, R. B., \& Christensen, L. B. (2004). Educational research: Quantitative, qualitative, and mixed approaches. Boston, MA: Allyn and Bacon.

Kalyani, L.D. (2006). An empirical investigation of the impact of organizational factors on the perceived job performance of shop floor employees of large scale garment industries in Sri Lanka. Sabaragamuwa University Journal, 6(1), 82 - 92.

Kenya National Bureau of Statistics (2014). Economic Survey 2014. Nairobi: Kenya.

Kenya National Cohesion and Integration Commission. (February, 2012). Briefs on Ethnic Diversity of Public Universities in Kenya. Vol. 3. 
INTERNATIONAL JOURNAL OF ACADEMIC RESEARCH IN BUSINESS AND SOCIAL SCIENCES

Vol. 8, No. 11, Nov, 2018, E-ISSN: 2222-6990 (C) 2018 HRMARS

Kenya National Human Rights Commission Report. (2011). Lest We Forget: The faces of Impunity in Kenya. Part 3.

Kirton, G. \& Greene, A. (2005). The Dynamics Of Managing Diversity. A Critical Approach, $2^{\text {nd }}$ Edn. Oxford: Elsevier Butterworth-Heinemann.

Korte, R. (2007). A review of social identity theory with implications for training and development. Journal of European and Industrial Training, Vol. 31(3).

Kothari, C.R. (2009). Research Methodology: Methods and Techniques. New Delhi. New Age International Publishers.

Kulik, C., Bainbridge, T. \& Hugh, T.J. (2006). Psychological Perspectives on Workplace Diversity. Pp. 25-52 in Konrad - Prasad - Pringle (2006): Handbook of Workplace Diversity. Sage Publications.

Kundu, S.C. (2001). Valuing Cultural Diversity; A study of employee reactions to employer efforts to value diversity in India. Proceedings of the $7^{\text {th }}$ Asia- Pacific Management ConferenceThe Great Asia in the $21^{\text {st }}$ century, University of Malaya, Kuala Lumpur, Malaysia and National Cheng Kung University, Tainan, ROC (2) pp. 635-646.

Kunze, F., Boehm, S., \& Bruch, H. (2013). Organizational Performance Consequences of Age Diversity: Inspecting the Role of Diversity-Friendly HR Policies and Top Managers' Negative Age Stereotypes. Journal of Management Studies, 50(3), 413442

Lawshe, C.H. (1975). A quantitative approach to content validity. Personnel Psychology, 28, 563575.

Loden, M., \& Rosener, J.B. (1991).Workforce America! Managing Employee Diversity as a Vital Resource. Burr Ridge, IL: Irwin.

Mahour, P. \& Stephanie, G. A. (2012). “Corporate Social Responsibility, Benchmarking, and Organizational Performance in the Petroleum Industry: A Quality Management Perspective". International Journal of Production Economics, 139 (2): 447-458.

Mellenbergh, G.J. (2008). Tests and questionnaires: Construction and administration. In H. J. Adèr \& G. J. Mellenbergh (Eds.) (with contributions by D. J. Hand), Advising on research methods: A consultant's companion (pp. 211-234). Huizen, The Netherlands: Johannes van Kessel Publishing. 
INTERNATIONAL JOURNAL OF ACADEMIC RESEARCH IN BUSINESS AND SOCIAL SCIENCES Vol. 8, No. 11, Nov, 2018, E-ISSN: 2222-6990 @ 2018 HRMARS

Michie, J. \& Sheehan, M. (1999). HRM Practices, R\&D expenditure and innovative investment: Evidence from the UK's 1990 Workplace Industrial Relations Survey. Industrial and Corporate Change, 8, 211-234.

Mugenda, O.M \& Mugenda, A.G. (2003). Research Quantitative and Qualitative Approaches. $2^{\text {nd }}$. Rev. Ed. Nairobi: Act press.

Munjuri, M.G. \& Maina, R.M. (2013). Effect of Workforce Diversity Management on Employee Performance in the Banking Industry in Kenya. DBA Africa Management Review. 2013;3 (No.1):1-21.

Nelson, D. L. \& Quick, J. C. (2011). Understanding Organizational behavior. Belmont, CA: Cengage South-Western.

Nemetz, P.\& Christensen, S.L. (1996).The challenge of cultural diversity: harnessing a diversity of views to understanding multiculturalism. Academy of Management Review .Vol.21, No.2.pp434-462.

Nunnally, J.C. (1978). Psychometric Theory, 2nd Ed. New York: McGraw-Hill.6Blau, P. M. 1977. Inequality and heterogeneity. New York: Free Press.

O'Flynn, J., Ricciotti, A., Nicholas, S., Lau, K., Sammarino, A., \& Fisher, N. (2001). The Theory of Diversity and Group Performance. Australian Centre for International Business, 1-54.

Omboi, B.M. \& Kamencu, S.M. (2011). The Effect of Performance Appraisal Systems on Employees in Kenya Tea Development Agency: A Survey of Selected Tea Factories in Meru County - Kenya. Research Journal of Finance and Accounting, Vol 2, No 3.

O'Reilly, C.A., Caldwell, D.F. \& Barnett, W. P. (1989). Work group demography, social integration, and turnover. Administrative Science Quarterly, Vol. 34, No. 1.

O'Reilly, C.A., III, Williams, K.Y., \& Barsade, W. (1998). Group demography and innovation: Does diversity help? In D. Gruenfeld (Ed.), Research on Managing Groups and Teams (Vol. 1, pp.183-207). St. Louis, MO: Elsevier.

Otike, F.W. (2009). Effects of workplace Diversity Management on organizational Effectiveness. European Journal of Business Management, 3 (21).

Perez-Floriano, J. \& Gonzalez, S. (2007). Risk, safety and culture in Brazil and Argentina. International journal of Manpower, Vol. 28(5) 403-417.

Pitts, D. \& Wise, L.R. (2010). Workforce Diversity in the New Millennium: Prospects for Research. Review of Public Personnel Administration, 30(1), 44-69. 
INTERNATIONAL JOURNAL OF ACADEMIC RESEARCH IN BUSINESS AND SOCIAL SCIENCES Vol. 8, No. 11, Nov, 2018, E-ISSN: 2222-6990 @ 2018 HRMARS

Renee, B. A. \& Daniel, F. (2002). Diversity and Incentives in Teams: Evidence from Corporate Boards, Journal of Financial Economics, 94:2, 291-309.

Republic of Kenya. (2010). Laws of Kenya. The Constitution of Kenya. National Council for Law Reporting, Nairobi.

Scott, C. L., \& Byrd, M. Y. (2012). Handbook of Research on Workforce Diversity in a Global Society Technologies and Concepts. USA: Business Science Reference.

Tajfel, H., \& Turner, J. (1985). The social identity of intergroup behavior. In S. Worchel \& W. Austin (Eds.), Psychology and intergroup relations: 7-24: Chicago: Nelson-Hall.

Terpstra, D. E. \& Rozell, E. J. (1993). "The relationship of staffing practices to organizational level measures of performance". Personnel Psychology, Vol 46: 27-48.

The Universities Act, Cap 201B. (1985). Special Issue of the Kenya Gazette Supplement.

Thomas, D. \& Gabarro, J. (1999). Breaking through: the making of minority executives in corporate America. Boston, MA: Harvard Business School Press.

Thomas, R. (2005). Building on the Promise of Diversity. New York: AMACOM.

Thomas, R. Jr. (1990). 'From Affirmative Action to Affirmative Diversity'. Harvard Business Review, $68,2,107-117$.

Torrington, D., Hall, L. \& Taylor, S. (2005). Human Resource Management. Sixth Edition. London: Pearson education Ltd.

Wiederman, M.W. (1999). "Volunteer bias in sexuality research using college student participants." Journal of Sex Research, 36: 59-66, doi: 10.1080/00224499909551968

Williams, K.Y. \& O'Reilly, C.A. (1998). Demography and Diversity in Organization: A Review of 40 years of Research. Research in Organization Behavior, 20, pg 77-140.

Willmott, A.S. \& Nuttall, D.L. (1975). The Reliability of Examinations at 16+. London: Macmillan Education.

Wilson, F.R., Pan, W. \& Schumsky, D.A. (2012). Recalculation of the critical values for Lawshe's content validity ratio. Measurement and Evaluation in Counseling and Development, 45(3), 197-210. 
INTERNATIONAL JOURNAL OF ACADEMIC RESEARCH IN BUSINESS AND SOCIAL SCIENCES Vol. 8, No. 11, Nov, 2018, E-ISSN: 2222-6990 @ 2018 HRMARS

Wrench, J. (2007). “Gathering Evidence for Racism and Discrimination in the EU: The implications for trade unions" Transfer: European Review of Labour and Research, Brussels, vol.3 (3):488-496. 